\title{
Impact of Feedstock Quality and Variation on Biochemical and
}

\section{Thermochemical Conversion}

\section{Chenlin Li ${ }^{1}$, John E. Aston ${ }^{2}$, Jeffrey A. Lacey ${ }^{2}$, Vicki S. Thompson ${ }^{2}$, David N. Thompson ${ }^{2, *}$}

${ }^{1}$ Biofuels and Renewable Energy Technology Department, Idaho National Laboratory, Idaho Falls, Idaho, USA.

${ }^{2}$ Biological and Chemical Processing Department, Idaho National Laboratory, Idaho Falls, Idaho, USA.

*Corresponding Author: David N. Thompson

Phone: (208) 526-3977; FAX: (208) 526-3150; Email: David.Thompson@inl.gov 


\begin{abstract}
The production of biofuels from lignocellulosic feedstock is attracting considerable attention in the United States and globally as a strategy to diversify energy resources, spur regional economic development and reduce greenhouse gas emissions. Because of the wide variation in feedstock types, compositions and content of convertible organics, there is a growing need to better understand correlations among feedstock quality attributes and conversion performance. Knowledge of the feedstock impact on conversion is essential to supply quality controlled, uniform and on-spec feedstocks to biorefineries. This review paper informs the development of meaningful feedstock quality specifications for different conversion processes. Discussions are focused on how compositional properties of feedstocks affect various unit operations in biochemical conversion processes, fast pyrolysis and hydrothermal liquefaction. In addition, future perspectives are discussed that focus on the challenges and prospects of addressing compositionally intrinsic inhibitors through feedstock preprocessing at regionally distributed depots. Such preprocessing depots may allow for the commoditization of lignocellulosic feedstock and realization of stable, cost-effective and quality controlled biomass supply systems.
\end{abstract}

Keywords: Feedstock quality, ash, alkali metals, pyrolysis, fermentation, hydrothermal liquefaction. 


\section{Introduction}

\subsection{Background}

Renewable biomass represents an abundant source of carbon neutral domestic energy, and its use for biofuels is attracting considerable attentions in the US and worldwide as a strategy to mitigate climate change, secure a constant energy supply, and improve rural economies[1]. The Billion-Ton Study update released by the US Departments of Energy (DOE), Agriculture (USDA) and DOE's National Laboratories in August 2011 predicts that there will be more than one billion dry tons of biomass sustainably available annually in the US for conversion to 85 billion gallons. With the continued development of biorefinery capacity and technologies, this amount of fuel may potentially displace approximately $30 \%$ of the nation's petroleum consumption by 2030 [1-4].

The success of biofuel and biochemical industries depends on a reliable supply of highquality biomass, available at a cost that enables meeting the cellulosic biofuel and business profitability targets $[5,6]$. The current technical focus is on the development of cellulosic feedstocks, e.g., non-grain, non-food-based feedstocks and on economically viable technologies to convert cellulosic material into transportation fuels and other products. The cellulosic feedstock types being considered include: 1) agricultural residues that are non-food based byproducts (e.g., corn stover); 2) energy crops including woody (e.g., hybrid poplar, willow) and herbaceous (e.g., switchgrass, miscanthus, sorghum, energy cane); 3) forest resources such as existing and re-purposed pulp and paper products, logging residues, and forest thinnings; and 4) industrial and other wastes which are from waste processing (e.g., municipal solid wastes, yard wastes, urban renewal wood waste) [2]. 
While the broad-scale use of these feedstocks is still emerging, existing biomass supply systems have been developed for mature agriculture, logging, food, and pulp and paper industries. This has fostered assumptions that the biomass quality specifications for the original applications are also appropriate for conversion to bioenergy. Although progress has been made in biomass harvesting, collection, and storage to improve operational efficiency, reduce material loss and drive down logistics costs, an emphasis on feedstock quality and its impacts on conversion are lacking $[5,6]$.

To further the economic growth of the biofuels industry, it is critical to understand that not all biomass is suitable for conversion into biofuels, biochemicals or biopower because biomass resources are inherently heterogeneous, have variable compositions and conversion properties, and can contain introduced soil and other endogenous contaminants that are detrimental to handling and downstream processing [6-8]. The viability of conversion facilities depends highly on supply systems that ensure low-cost, high-volume, and quality controlled feedstock supplies. A variety of conversion pathways can be used to convert renewable feedstocks into fuels and chemicals. However, these conversion technologies will necessarily have different requirements for feedstock quality.

\subsection{What is Feedstock Quality?}

At the highest level, the physical characteristics and chemical composition of the biomass are the most important indicators of a biomass source's potential for conversion into biofuels. The requirements are markedly different among conversion processes for these quality indicators. For example, biochemical conversion of biomass to ethanol is typically much more dependent on cellulose and hemicellulose content and less susceptible to ash content, and thus high ash herbaceous feedstocks such as corn stover are commonly used for biochemical 
pathways [9-11]. In contrast, low ash woody biomass with high lignin content is typically more favored in thermochemical conversion processes such as pyrolysis and gasification, because they produce high yields of products and have decreased catalytic poisoning, slagging, and equipment fouling/corrosion problems as compared to herbaceous feedstocks $[5,8,12,13]$. If the full potential of the billion tons of biomass is to be achieved while ensuring year-round feedstock supply and taking advantage of conversion economies of scale, it will be necessary to devise ways to improve the quality attributes of locally available biomass sources for use in conversion processes that they may not be perfectly suited for. Hence, a deeper understanding of the meaning of feedstock "quality" and its cost and yield impacts on specific conversion technologies is critical.

Feedstock quality attributes that impact conversion performance and process economics can be divided into three categories: physical attributes, structural attributes and compositional attributes (Figure 1). Dividing feedstock quality attributes into these categories considers feedstock quality at three different scales: physical attributes are generally at the macroscale, structural attributes are generally at the microscale, and compositional attributes are at the molecular scale. Physical attributes primarily affect feedstock processability and drive the logistics, structural attributes primarily affect convertibility and thus drive selection of the conversion process, while compositional attributes primarily affect product yield and drive the selection of feedstock. However, the impacts of these attributes are not always independent but can overlap. For example, a compositional attribute such as the presence of inhibitors can affect both yield and convertibility depending on the conversion process.

Table 1 summarizes the primary impacts of some key feedstock quality attributes on feedstock selection, logistics and conversion. At the macroscale, feedstock type, particle size and 
shape, moisture content, energy density, bulk density, hygroscopicity, and flowability, can affect feedstock handling, storability, reactivity, product yield, and transportation cost. At the microscale, cell wall structure, cellulose crystallinity, degree of polymerization (DP), porosity, and surface area, can affect the biomass recalcitrance and reactivity. Finally, at the molecular scale, the feedstock's compositional properties including ash content and species (alkali metals, alkaline earth metals, heavy metals, silica, chlorine, sulfur, etc.), extractives, structural carbohydrate contents, $\mathrm{C}_{5}$ and $\mathrm{C}_{6}$ sugars present, lignin content and its monomer composition, elemental content (carbon, hydrogen, oxygen and nitrogen), etc., can directly impact product yield, equipment wear, conversion cost and the need for wastewater treatment. In addition at this scale, various inhibitors generated during conversion (sugar and lignin degradation products) can also pose direct or potential inhibitory effects on the conversion pathway, product yield and process cost.

There are inherent advantages of choosing a single feedstock for use in both biochemical and thermochemical processes, and process designs must always factor in anticipated variations in their chosen feedstock [14]. The best case is when there is a guaranteed year-round supply of a single type of biomass in a local area. Unfortunately for much of the billion tons of biomass, this is the exception rather than the rule. Thus, as noted earlier it will be necessary to devise ways to improve the quality attributes of locally available but less-preferred biomass sources so that they can also be utilized. Developing robust processes that can handle these biomass sources will require a full understanding of the impacts of feedstock quality variation on the various conversion pathways, i.e., feedstock convertibility, product yield and product quality [8, $15,16]$. 
The ultimate goal of this review is to inform the development of meaningful feedstock quality specifications for different conversion processes. To that end, we will first review how compositional properties of feedstocks affect various unit operations in biochemical conversion processes, fast pyrolysis and hydrothermal liquefaction (HTL). In the future perspective, identify existing technologies that could be employed to meet these quality specifications. Inhibitors generated directly from the convertible fractions of the biomass during conversion (sugars for biochemical processes, and high molecular weight organics for thermochemical processes) will not be considered in this review.

\section{Impact of feedstock quality attributes on conversion pathways}

There are various types of conversion processes for converting biomass into fuels and chemicals. Three major pathways and their primary unit operations are shown in Figure 2, providing general process flows [8, 17-20]. Biochemical conversion of lignocellulose starts with thermochemical pretreatment to disrupt the compact structure of the plant cell walls, and is followed by enzymatic hydrolysis to depolymerize the polysaccharides to sugars, leaving a lignin-rich residue. The sugars are then converted into a variety of fuels and chemicals via biological fermentation. Alternatively, lignocellulose can be converted into to bio-oils through pyrolysis or HTL. Pyrolysis is the thermochemical decomposition of dry organic matter (moisture content below $10 \%$ mass fraction) in the absence of oxygen at high temperatures (450$600{ }^{\circ} \mathrm{C}$ ) and atmospheric pressure $[12,21]$. In contrast, HTL is performed in presence of water at lower temperatures $\left(250-370{ }^{\circ} \mathrm{C}\right)$ and higher pressures (2-20 MPa) and can convert biomass with high moisture content [22, 23]. These different conversion technologies have markedly different requirements for feedstock quality; the details of feedstock quality impacts on these three pathways are discussed below. 


\subsection{Biochemical Fermentation to Ethanol}

Numerous pretreatment strategies have been developed to enhance the reactivity of cellulose and to increase the yield of fermentable sugars. An effective pretreatment is characterized by several criteria: avoiding size reduction, preserving hemicellulose, limiting formation of inhibitors due to degradation products, minimizing energy input, and being costeffective. Microbial fermentation can be performed through separate hydrolysis and fermentation or through simultaneous saccharification and fermentation. In addition, consolidated bioprocessing, in which the fermenting microorganism also contributes by producing cellulolytic enzymes, is under development $[7,24]$. In this section we focus on the leading dilute acid pretreatment, enzymatic hydrolysis and the subsequent ethanol fermentation by the most common ethanol producer, the yeast Saccharomyces cerevisiae.

\subsubsection{Effect of feedstock quality on pretreatment and enzymatic hydrolysis}

Key feedstock attributes that impact pretreatment and enzymatic hydrolysis are shown in Table 2. Cellulose crystallinity and DP have been considered as important features that affect pretreatment and enzymatic performance [25]. The intra- and inter-molecular hydrogen bonds in the linear cellulose chains promote aggregation into a crystalline structure and give cellulose a multitude of partially crystalline fibrous structures and morphologies [26]. During dilute acid pretreatment, hydrolysis of amorphous cellulose can result in an increase in cellulose crystallinity $[25,27,28]$. It has been observed that crystallization of amorphous cellulose produces increased amounts of crystalline allomorphs at longer pretreatment residence time [28]. As the pretreatment temperature increases, the conversion from amorphous cellulose to crystalline structure decrease and the formation of less ordered cellulose allomorphs increased [28]. It is generally accepted that crystalline cellulose has higher resistance to enzyme hydrolysis 
than amorphous cellulose. Zhao et al., [29] reported that the a- cellulose hydrolysis rate can be increased more than double with the decrease of cellulose crystallinity index from 0.773 to 0.523. However, there is not a direct correlation between crystallinity and cellulose digestibility in lignocellulosic materials. This is because other properties including porosity, surface area, lignin/hemicellulose contents and distribution, and other macro-physical properties also play a role $[30,31]$.

Cellulose DP can be as high as 17,000, although it is more commonly in the range of 800-10,000 [25, 26]. High DP cellulose has fewer reducing ends and contributes to biomass recalcitrance, and reduction of DP relies highly on pretreatment severity and enzyme usage [25, 32]. Dilute acid pretreatment results in partial cellulose hydrolysis, leads to a reduction of DP especially at high pretreatment severity, and increases the enzymatic digestibility of cellulose $[25,28,32]$. Interestingly, regardless the feedstock used, acid pretreatment is often reported to reduce cellulose DP to "leveling off” DP values with amorphous cellulose rapid hydrolysis at the initial phase and crystalline cellulose hydrolysis at the slow plateau phase [33-36]. For example, a recent research indicated that the reduction of DP in poplar cellulose during acid pretreatment at $170^{\circ} \mathrm{C}$ reached quickly at approximately $69 \%$ within $8.5 \mathrm{~min}$, but increased slowly to approximately $86 \%$ at $26.8 \mathrm{~min}$ [34]. Similarly, Foston et al., compared behaviors of cellulose in poplar and switchgrass during acid pretreatment at $160^{\circ} \mathrm{C}$, and observed consistent rapid and slow phases with the increase of residence time [36].

During pretreatment, acid solubilizes hemicellulose, disrupting the lignocellulosic matrix and thereby making the cellulose more accessible to saccharifying enzymes [27]. Biomass also contains enzymatic and microbial catalyst inhibitors that can be released from hemicellulose, 
lignin or ash, during the pretreatment and enzymatic hydrolysis, affecting enzyme and fermentation performance [6].

Hemicellulose chains are extensively acetylated, and acetyl groups have been shown to contribute to biomass recalcitrance $[25,37]$. The acetyl groups are generally more abundant in hardwoods than softwood and herbaceous biomass [14]. They can restrict cellulase accessibility and inhibit their productive binding to cellulose. It was also found that acetyl groups bound to the xylan backbone and hindered cellulose access to the $\beta-1,4$ glycosidic linkage [37-39]. During dilute acid pretreatment, the acetyl groups are released to the reaction medium during the hydrolysis of hemicellulose. Although the deacetylation of biomass provides an in-situ source of acetic acids that further catalyze xylan decomposition, it also inhibits subsequent enzymatic saccharification and fermentation [7, 25, 38].

Lignin is considered to be the most recalcitrant component of lignocellulose, primarily in the secondary cell wall. Acid soluble lignin fragments released during pretreatment can cause irreversible cellulase loss during enzymatic saccharification, and the remaining solid lignin restricts enzymatic hydrolysis by physically impeding the accessibility of cellulase to cellulose, and also unproductively binds cellulose enzymes [40-42]. For example, dilute acid pretreated corn stover was observed to have the highest levels of non-recoverable cellulase, as compared to other pretreatment methods [42]. It is generally accepted that the lower the lignin content, the higher the bioavailability of the polysaccharides for bioethanol generation [25]. However, one recent study identified several unusual Populus species that did not follow the dependency of sugar release performance on lignin content [43]. It has been suggested that along with lignin content, other prominent lignin related factors that impact biomass digestibility include lignin composition, its chemical structures, lignin-carbohydrate complex linkages, and synergistic 
effects among the cell wall components in biomass and their corresponding chemical changes upon dilute acid pretreatment [25].

Delignification requires thermochemical pretreatment to disrupt the cell wall structure, remove the lignin, and improve the enzyme accessibility and digestibility of biomass. Dilute acid pretreatment solubilizes the hemicellulose, but doesn't lead to significant delignification.

Instead, several studies have found that the acid insoluble (Klason) lignin content of dilute acid pretreated material is often higher than that of the starting materials [27, 44]. This relative higher lignin content observed in the pretreated biomass can be attributed to the thermal decomposition of polysaccharides under acidic conditions. Furthermore, this phenomenon has also been hypothesized to be the result of polymerization of polysaccharide degradation products (such as furfural) and/or repolymerization of these products with lignin to form a lignin-like material called pseudo-lignin [41, 44-46]. Pseudo-lignin has been observed to consist of spherical structures that deposit on cell surfaces in pretreated biomass, and behave as a physical barrier that irreversibly binds with enzymes, as well as inhibit enzymes and reduce sugar yields [25, 44, 46].

Lignin or its fragments were also reported to migrate to the biomass surface during acid pretreatment where they deposited as droplets [40, 47]. Using SEM and TEM imaging, it was shown that dilute acid pretreatment above the melting temperature of lignin induces coalescence into larger molten bodies that migrate within and out of the cell wall, and then redeposit as droplets on the surface of the cell walls $[40,47]$.This phenomenon may also occur with acid soluble lignin that dissolves during the pretreatment and may precipitate on cooling to form deposits on the biomass. Similar to the effects of pseudo-lignin, redeposited lignin droplets on the biomass surface were observed to have detrimental impacts on enzymatic hydrolysis [40, 44, 
48]. This was attributed to its decreased enzyme access to the cellulose as well as irreversibly binding the cellulase, although the exact mechanism of this cellulase-lignin interaction was unclear [42].

Structural changes of lignin during dilute acid pretreatment, such as cleavage of aryl ether linkages also affect cellulose accessibility and enzymatic hydrolysis [25, 26]. For example, a recent study of structural changes in corn stover lignin during acid pretreatment found that the lignin syringyl/guaiacyl (S/G) ratio gradually increased from less than 1 to greater than 1 with increasing pretreatment temperature, which implies that more syringyl units are released from lignin depolymerization of aryl ether linkages than guaiacyl units [49]. Their results showed that the production of condensed phenolic units also correlate with increase in pretreatment temperature up to $180^{\circ} \mathrm{C}$, beyond which point condensation reactions may overtake hydrolysis of aryl ether linkages as the dominant reactions of lignin, thus leading to decreased cellulose accessibility [49]. The S/G ratio also determines the dependency of enzymatic sugar release on lignin content. Studer et al [43] found a strong negative correlation between enzymatic sugar release and lignin content for pretreated poplar with an $\mathrm{S} / \mathrm{G}$ ratio $<2.0$. Sugar release was observed to be higher with $\mathrm{S} / \mathrm{G}>2.0$ and the negative influences of lignin were less pronounced. Furthermore, it was observed that phenolic compounds affect enzymatic activity by inducing protein precipitation and also inhibition of enzymatic hydrolysis [50].

The ash contained in harvested biomass originates from two main sources, i.e., introduced ash from soil, rocks, and other forms of inorganic contamination during the harvest and collection process, and physiological ash consisting of silica and various micro- and macronutrients within in the plant tissues that are naturally present through biological processes [5154]. Different parts of the plant may have optimal uses based on their unique chemical 
compositions and/or physical properties $[55,56]$, because these ash elements are not uniformly distributed throughout the plant [57]. Generally, the ash content of herbaceous biomass is higher than that of woody biomass. While ash contents less than $1 \%$ (dry basis) are expected for debarked wood, different herbaceous biomass types have reported values ranging from less than $2 \%$ up to $8-10 \%$ or even up to $25 \%$ for rice husks $[8,51,56,58]$. In various waste sources, the ash content may often be as high as $30-50 \%$ and is only scarcely less than $10 \%[51,59]$.

Specific ash species in biomass feedstocks can be problematic for processes that convert the feedstocks to fuels for transportation and power generation purposes. However, their effects on dilute acid pretreatment and enzymatic hydrolysis have not been fully clarified [56]. The soil ash have been found to reduce the effectiveness of dilute acid pretreatment and lower the xylose yield, which can be correlated to soil buffering capacity and neutralization a fraction of the acid used in pretreatment $[60,61]$.

\subsubsection{Effect of pretreatment hydrolysate characteristics on fermentation}

During the fermentation of dilute acid hydrolysates, inhibitory compounds from the original biomass and those released during pretreatment and hydrolysis lower the cell growth and decrease ethanol productivity [7, 62-64], as summarized in Table 3. Note that sugar decomposition products are not considered here, as their presence depends on pretreatment process conditions and they originate from the convertible organic fraction of the feedstock.

Among these inhibitors, acetic acid has been studied the most. Its concentration varies strongly depending on the feedstock type and the pretreatment severity [7, 65]. At the normal fermentation $\mathrm{pH}$ of 5.5, which is close to acetic acid's pKa of 4.75, it exists in both associated and dissociated forms $[65,66]$. Two mechanisms have been proposed by Russell to explain the inhibitory effect: uncoupling of metabolism and intracellular anionic accumulation, both of 
which result in an intracellular $\mathrm{pH}$ drop and lead to cell death [66]. Additionally, acetic acid has also been shown to interact antagonistically with other process inhibitors generated from sugar degradation, i.e., formic acid, levulinic acid, furfural and HMF, and cause greater decrease of the cell growth [7]. It is difficult to prevent the formation of acetic acid because it is intrinsic to the lignocellulosic feedstock. Currently, pretreatment optimization and hydrolysate detoxification and conditioning are needed prior to fermentation, which increases the process costs.

Small water soluble phenolic extractives as well as aromatic compounds (Table 3) released from lignin during pretreatment also inhibit both microbial growth and affect product yields [7]. Phenolic compounds such as vanillin, syringaldehyde, and ferulate are major constituents of lignin and can also be linked to hemicellulose in some biomass substrates, for example, in grasses. These compounds can embed themselves into the cell membrane of organisms, causing a loss of integrity. Agblevor et al. applied ${ }^{13} \mathrm{C}-\mathrm{NMR}$ (Carbon-13 Nuclear Magnetic Resonance) to identify the functional groups in corn stover hydrolysates and showed that most of the inhibitory compounds are lignin derived, primarily from ferulic or p-coumaric acid and less significantly from syringyl groups [67]. Phenolic extractives can also inhibit the fermentation [7]. Lower-molecular-weight phenolic acids act similarly to weak acids with respect to disruption of intracellular $\mathrm{pH}$, decreasing ATP production in yeast, and have been shown to be more toxic $[63,64]$. The mechanism of toxicity has not yet been elucidated largely due to a lack of accurate qualitative and quantitative analyses in the literature [68].

Current methods of avoiding these inhibitors involve selection of processes that are either severe enough to remove much of the lignin, or very mild such that the lignin remains intact [ 63 , $64,69,70]$. Because of the complexity of the problem, several detoxification schemes have been investigated, including overliming $[67,71,72]$, solvent extraction $[73,74]$, steam treatment $[75$, 
76], and fungal treatment $[77,78]$. While overliming has been found to be one of the most effective methods for detoxifying various biomass hydrolysates [67], it is notable that all of these detoxification methods increase process costs. In addition, studies have shown that $S$. cerevisiae has been engineered by overexpression of enzymes conferring improved resistance to fermentation inhibitors, such as phenolics [79], and organic acids [80, 81], suggesting the promising alternative approaches.

Inorganic compounds from ash, such as alkali metals, alkaline earth metals and heavy metals can also inhibit yeast fermentations [82]. One study compared the individual effects of sodium, potassium, calcium and magnesium chloride salts, which are the most common metals in ash, on yeast growth [83]. Although $S$. cerevisiae is relatively salt tolerant compared other yeast strains [84], their results showed that all of these chloride salts exerted a significant antimicrobial effect on the cell growth cycle [83].

Specific information available in the literature on the effect of individual inorganic ions is summarized in Table 3, including minimum inhibitory concentration (MIC) and non-inhibitory concentration (NIC) data of several metals [83]. Intracellular ratio of $\mathrm{Na}^{+} / \mathrm{K}^{+}$was found to be more important than the absolute concentration of sodium, and should be preferably kept low [7]. In one study, $\mathrm{CaCl}_{2}$ showed a similar effect to $\mathrm{NaCl}$, while $\mathrm{KCl}$ and $\mathrm{MgCl}_{2}$ were progressively less inhibitory [9]. Another study investigated the effects of several different salts on the yeast and found that the inhibition decreased in the order of $\mathrm{CaCl}_{2},\left(\mathrm{NH}_{4}\right)_{2} \mathrm{SO}_{4}>\mathrm{NaCl}, \mathrm{NH}_{4} \mathrm{Cl}>$ $\mathrm{KH}_{2} \mathrm{PO}_{4}>\mathrm{MgCl}_{2}>\mathrm{MgSO}_{4}>\mathrm{KCl}$ [85]. Furthermore, inorganic salts also show synergistic inhibition of cell growth when they interact with acetic acids and sugar degradation products [7, 63]. Heavy metal ions such as iron, chromium, copper, nickel, although typically low in biomass composition, can have inhibitory to yeast growth and metabolic pathway as well $[74,78,86,87]$. 
It should be noted that high salt concentrations leading to osmotic stress can be caused by chemicals added during pretreatment, conditioning and hydrolysis, as well as process equipment [7]. To minimize inhibition from inorganic salts, preprocessing operations prior to the refinery is necessary to reduce the ash contents originally from biomass. Alternatively, pretreatment that does not require significant $\mathrm{pH}$ adjustment might be utilized, and choosing a salt tolerant fermentation organism can also be a promising solution.

\subsection{Ex-Situ Catalytic Fast Pyrolysis Pathway}

During ex-situ fast pyrolysis, biomass is rapidly heated in the reactor to approximately $500^{\circ} \mathrm{C}$ in less than two seconds and in the absence of oxygen to produce pyrolysis vapors $[8,12$, 88]. The vapor is passed through a cyclone to remove char and solid particulates, sent to a catalyst bed that partially deoxygenates and stabilizes the vapor, and subsequently a liquid biooil is condensed and undergoes further hydrotreating to produce hydrocarbon biofuel blend stocks $[89,90]$. Feedstock compositional attributes affect multiple parts of the pyrolysis process and this section will focus on the effects on bio-oil yield and quality as well as on the bio-oil catalytic upgrading process performance.

\subsubsection{Effect of compositional properties on fast pyrolysis}

Table 4 demonstrates that fast pyrolysis performance is mainly affected by hemicellulose and ash. Hemicellulose is mainly degraded into acids and gases [91] and influences pyrolysis in two ways. The first is liberation of acetic acid from biomass due to deacetylation of hemicellulose and causes corrosion of vessels and pipework $[12,13]$. This currently results in the need for more expensive corrosion resistant materials, and results in increased captial costs [92]. The second effect results from hemicellulose linkages with lignin, and the hemicellulose/lignin ratio has a significant impact on the formation of water and organics during pyrolysis. The 
presence of hemicellulose can limit the devolatilization of inorganics, increase char formation, and reduce bio-oil yield and quality [13].

Ash in the biomass contains alkali metals, which are very active catalysts. Trace quantities of these metals can affect the pyrolysis rate, product yield, degradation temperature, and can change the reaction pathways and decomposition mechanisms $[8,12,93]$. Alkali metals cause fragmentation of the monomers that comprise the natural polymer chains, rather than the predominant depolymerization that occurs in their absence [92]. According to the Waterloo model developed by Liden et al. [94], cellulose pyrolysis has two major alternative routes for degradation, depending on the amount of alkali metals present. If high levels of alkali metals are present, the degradation mechanism favors fragmentation (ring scission) producing lower molecular weight compounds such as hydroxyacetaldehyde. Lower alkali metal content promotes a depolymerization mechanism resulting in higher molecular weight compounds such as levoglucosan and $\beta$-D-fructose. The yield and optimum conditions vary as the alkali metals in the biomass vary [94].

Potassium and calcium are the major cations present in biomass, along with minor amounts of sodium, magnesium and other elements such as phosphorous and chlorine [16, 92, 95]. Several studies have compared the influence of individual ash species on the performance of pyrolysis [95, 96]. Potassium is most active, followed by sodium [95]. They cause secondary cracking of vapors and reduce bio-oil yield and quality. Depending on the concentration of metals, the effect can be more severe than char cracking [12, 96, 97]. In contrast, calcium, iron and magnesium have very little catalytic effect [95]. The non-metal compound, silica, is generally considered inert in pyrolysis reactions [8]; however, a recent study conducted by Bulushev and Ross [98] revealed that $\mathrm{SiO}_{2}$ can also be secondary catalyst for the cracking of 
large polymeric molecules such as oxygenates and increases char formation and gas production. In addition, phosphorus was also found to have a strong catalytic effect, that increases char formation and promotes different product distributions similar to those seen in the presence of alkali metals [89]. Chlorine can cause corrosion damage to the vessel surface. Its reaction with alkali metals such as potassium and sodium can also cause slagging. Chlorides such as alkali and alkaline earth metal chlorides, copper chlorides and iron chlorides increase levoglucosan yields and affect the bio-oil product distribution $[95,99,100]$. Furthermore, heavy metals, although typically low in biomass, can cause environmental problems, affect char/ash utilization and disposal and require cleaning $[8,51,101]$.

\subsubsection{Effect of bio-oil chemical properties on upgrading}

Table 4 also summarizes the impact of feedstock chemical properties, primarily ash and ash species, on bio-oil upgrading. The difficulties and the costs of bio-oil upgrading in the production of liquid fuels and chemicals depend highly on the quality of bio-oil produced from pyrolysis [96]. Residual alkali metals are present in the bio-oil, and even at low concentrations can accelerate aging of the bio-oil and catalyze significant chemical changes during storage and upgrading $[12,21,96]$. Alkali salts in the oils were found to deposit on the catalyst surface, poisoning active sites and causing catalyst deactivation [89]. Phosphate deposits were observed at the front of the catalyst bed, and it was hypothesized that alkali metals catalyzed the formation of these deposits and led to catalyst deactivation. When alkali was not present, phosphoric acid was formed instead of phosphates, which in turn accelerated the rate of coke deposition [89].

Alkali metals and other inorganic species are known to exist in pyrolysis vapor $[12,102$, 103]. For example, N, S, Cl can volatilize during rapid heating and poison catalysts. Formation of $\mathrm{H}_{2} \mathrm{~S}$ in the pyrolysis vapor inhibits the deoxygenation reactions on the catalyst surface [104]. 
Formation of $\mathrm{SO}_{\mathrm{x}}$ and $\mathrm{NO}_{\mathrm{x}}$ can produce harmful emissions [105-108], whereas $\mathrm{HCl}$ formed is corrosive and causes damages to reactors [109]. As most alkali metals in biomass are either water-soluble or ion-exchangeable and small portions of them may also vaporize during pyrolysis $[96,102,103]$, if they are not removed or scrubbed upstream, at pyrolysis temperature, they are likely to deactivate the catalyst rapidly by blocking active sites and accelerating coke formation $[1,12]$.

Mitigating the effects of these inorganic contaminants requires additional unit operations, but with increased capital and operational costs. Hot vapor filtration is a promising operation that can reduce the ash content of the bio-oil to less than $0.01 \%$ and the alkali content to less than 10 ppm, much lower than can be achieved with the cyclones that are commonly used, providing a higher quality product with decreased char $[12,110]$. Alternatively, a guard bed of identical catalyst could be placed upstream of the upgrading reactor but again at added cost; the potential for development of more robust catalysts that are tolerant to these inorganic components is seen as promising [89].

\subsection{Hydrothermal Liquefaction (HTL)}

HTL of biomass is the thermochemical conversion of biomass into liquid fuels by processing in a hot, pressurized water environment for sufficient time to break down the solid biopolymeric structure to liquid components. Typical hydrothermal processing conditions are $250-350{ }^{\circ} \mathrm{C}$ of temperature with operating pressures from 2 to $20 \mathrm{MPa}$. The bio-crudes produced from HTL process have the properties that fall short of diesel or biodiesel standards, require upgrading to remove oxygen, produce hydrocarbon fuels and meet the current fuel property standards [111]. The upgrading process discussed here is based on catalytic hydrotreating, analogous to petroleum product hydrotreating technology [18]. 
In comparison with pyrolysis, which requires low moisture content feedstocks, rapid heating and quenching rates, and high temperature, HTL presents a potentially viable route for direct conversion of materials to liquid fuels without the need for drying. The nature of this process allows a wide range of feedstocks (i.e., lignocellulosic biomass, municipal waste, sewage, manure, and algae) to be converted at solids concentrations that can be pumped (typically 5-35\% dry solids), and at the same time allows complex mixtures of feedstocks to be processed [18, 111-113]. Notably, the ash content can vary significantly among these feedstocks, ranging from $3-20 \%$ for lignocellulose to $20-50 \%$ for municipal solid waste and sewage.

Table 5 summarizes the impact of compositional attributes on HTL conversion of biomass. A high ash content means less organic materials are available for conversion into biocrude, leads to an increase in solid residues, and reduces the bio-crude yield [113]. This requires solid/liquid separation step following HTL to produce solids-free and mineral-free bio-crude. Introduced ash can cover the surface of the organic matter and hamper mass transfer and thermochemical reactions of the organic matter with subcritical water [114, 115].

HTL doesn't require a catalyst to be added, however, a significant amount research on improving HTL through the addition of catalysts has been undertaken. The most commonly considered catalyst has been the addition of alkali to modify the ionic medium in such a way that favors certain base-catalyzed condensation reactions and leads to aromatic oil production [18]. The alkali and alkaline earth metals originating from the biomass can thus serve as natural catalysts in HTL, in contrast to their inhibitory effects on biochemical conversion and pyrolysis. Feng et al. [116] investigated the effects of ash and ash composition on bark liquefaction by comparing the liquefaction efficiencies between crude bark and deashed bark from pine, spruce and birch. Deashing decreased both the conversion rate and the bio-crude yield for all barks, 
suggesting that the ash played a catalytic role in the liquefaction; this was confirmed through the addition of $\mathrm{K}_{2} \mathrm{CO}_{3}$ or $\mathrm{Ca}(\mathrm{OH})_{2}$ into the deashed barks prior to conversion. The addition of $\mathrm{K}_{2} \mathrm{CO}_{3}$ or $\mathrm{Ca}(\mathrm{OH})_{2}$ to the deashed bark also improved the quality of the resulting biocrudes in terms of lower $\mathrm{O} / \mathrm{C}$ ratio and an increased $\mathrm{HHV}$. For other alkali catalysts such as $\mathrm{NaOH}, \mathrm{Na}_{2} \mathrm{CO}_{3}, \mathrm{KOH}$ and $\mathrm{K}_{2} \mathrm{CO}_{3}$, their effects on $\mathrm{HTL}$ of woody biomass were ranked as: $\mathrm{K}_{2} \mathrm{CO}_{3}>\mathrm{KOH}>\mathrm{Na}_{2} \mathrm{CO}_{3}>$ $\mathrm{NaOH}$ [116]. Interestingly, effect of $\mathrm{K}_{2} \mathrm{CO}_{3}$ on heavy oil yield was found to be dependent on the lignin content of the feedstock: the lower the lignin content, the weaker the effect [116].

Unlike the hazardous products of combustion, such as ammonia, $\mathrm{NO}_{\mathrm{x}}$, etc., $\mathrm{HTL}$ converts heteroatoms present in biomass into harmless byproducts [112]. Nitrogen heteroatoms present in biomass, converts primarily to $\mathrm{N}_{2}$, with some $\mathrm{N}_{2} \mathrm{O}$ formed. Sulfur, chlorine, and phosphorous are oxidized to their respective inorganic acids, which can be that are neutralized by adding suitable base [117]. However, the presence of acids during hydrothermal processing can harm vessel linings and require additional precautionary measures [112].

Information the effects of lignocellulosic biomass compositional attributes on the catalytic hydrotreating of HTL bio-crude is limited, but could be similar to those for pyrolysis bio-oil because the reactions being catalyzed are similar [111]. The effects of nitrogen and sulfur would likely lower in comparison with the pyrolysis process, however, they still may contribute to air pollution with combustion into $\mathrm{NO}_{\mathrm{x}}$ and $\mathrm{SO}_{\mathrm{x}}$ if not removed from the biocrude prior to upgrading [118].

\section{Future Perspectives}

Currently, compositional quality specifications for biomass are limited to sugar content, organic content and total ash. While these measures largely determine the yield potential of the feedstock, other feedstock quality attributes that go beyond the content of convertible organics 
can strongly influence the behavior of the biomass in the reactor in ways that affect the actual yield, product quality, catalyst performance and reactor life cycle. To date, many such feedstock quality attributes, e.g., ash species and other intrinsic inhibitors are not generally given consideration commensurate with their impact.

Biorefineries employing different conversion pathways for biofuels production require feedstock commodities with different quality specifications. Despite the conversion inhibitors generated from the processes, which are not the focus of this review paper, it is envisioned that biochemical conversion and ethanol production are mostly impacted by biomass recalcitrance and inhibitors contributed by cellulose, hemicellulose and lignin composition and structures, and less sensitive to ash contents and species. In contrast, the performance of thermochemical conversion such as fast pyrolysis and HTL are more affected by alkaline metals, chlorine, sulfur, silicon, etc., in the ash compositions, but less affected by native inhibitors or inhibition precursors from the structural carbohydrates and lignin. As such, these feedstock properties should be recognized as important quality attributes considered for mitigation through feedstock selection, formulation and preprocessing.

Solving the problems of feedstock variability and supplying quality controlled, uniform and on-spec feedstocks to biorefineries are critical to achieve competitive biofuels production. Approaches and solutions need to be taken to mitigate the impact of feedstock quality and viability to realize a sustainable and economical conversion. A new feedstock supply concept, regionally distributed feedstock preprocessing depots, is currently under development with the support of US DOE, aiming to improve feedstock supply system efficiencies and capture cost savings by locating feedstock collection and preprocessing centers close to feedstock production locations $[6,119-122]$. These preprocessing depots will manage a single feedstock type or a 
variety of feedstock types and apply advanced preprocessing treatments, including mechanical and chemical treatments along with feedstock formulation and blending, to improve feedstock composition and quality targeting at specific conversion in the refineries.

The advanced preprocessing technologies at depots will have the ability manage feedstock quality attributes by removing total ash, specific ash species and process inhibitors such as acetate and phenolic derivatives. Currently, mechanical separation such as size fractionation and air classification have been proven successful in concentrating and removing introduced ash from biomass, and producing anatomical distinct fractions. Automated sorting based on the spectral properties of the biomass is an emerging technology that could enable separations based upon unique chemical signatures in the biomass, such as carbohydrate content, lignin content, or properties affecting the convertibility of the material.. In particular, these separated fractions with different physical and chemical properties have great potential to be used in certain conversion pathways with increased values [52, 123]. Conversely, low quality fractions may be subjected to disposal via landfilling or used as a biopower feedstock.

Alternately, they may be chemically preprocessed to an extent that they may be recombined with higher quality fractions to provide a summation of fractions that meet given feedstock quality specifications.

Chemical preprocessing using low-severity hydrothermal, dilute acid, alkaline extraction or a non-aqueous solvent extraction is another promising approach for the selective mitigation of feedstock quality attributes. Water washing at temperatures from ambient to near boiling can remove exogenous ash components such as sodium, alumina, iron and silica introduced via soil entrainment [108, 124]. However, the removal of physiological ash components, including the bulk of the alkaline earth and alkali metals, which are inhibitory to thermochemical conversions, 
may require dilute-acid leaching [125] or other chemical treatments. Beyond ash removal, chemical treatments may provide other improvements to feedstocks. For example, alkaline extraction deacetylates the feedstock, improving performance in biochemical conversions [126]. Although aqueous treatments such as water washing, dilute-acid leaching and alkaline extractions can effectively manage ash and other feedstock quality attributes, they also may incur significant costs due to chemical management and drying costs. A potential solution is to combine chemical and mechanical preprocessing by chemically treating the minimum amount of mechanically generated fractions necessary to meet a given feedstock quality specification while minimizing preprocessing costs. In addition to using such formulation methods to reduce the amount of feedstock requiring chemical preprocessing, further research should identify more cost effective chemical preprocessing technologies, such as the use of non-aqueous polar solvents to reduce drying costs, while still effectively removing via liquid extraction.

Finally, formulation and blending offer another potential solution to produce feedstocks that meet quality specifications. This approach is already utilized in other industries such as animal feed to optimize nutrient content, grain blending to adjust for moisture content, and coal blending to reduce sulfur and nitrogen content for power generation. Formulation can be used with whole feedstocks to blend together high and low quality materials to produce a final blend that mitigates the effects of undesirable components in whole biomass resources such as ash, sulfur, nitrogen, etc., and balance the carbohydrate and lignin contents in various types of feedstocks to meet the convertibility and yield targets of different conversion pathways. Additionally, fractions generated from either mechanical or chemical preprocessing or both can be blended to achieve the convertibility and yield targets. Formulation combined with 
mechanical and chemical treatments will also lower feedstock costs and increase feedstock quantities since it allows additional lower cost and lower quality feedstocks to be used.

Feedstock quality attributes can have a significant impact on different conversion pathways. Biomass quality can impact material handling, conversion efficiency, and product yield and quality. Integrated with the regionally distributed depot concept, these advanced preprocessing technologies offer great potential to enable the commoditization of lignocellulosic feedstock and the realization of cost-effective quality management for enhanced performance in conversion reactions.

\section{Acknowledgement}

This work is supported by the U.S. Department of Energy, Office of Energy Efficiency and Renewable Energy, Bioenergy Technologies Office, under DOE Idaho Operations Office Contract DE-AC07-05ID14517. 


\section{Reference}

[1] Ragauskas AJ, Williams CK, Davison BH, Britovsek G, Cairney J, Eckert CA, et al. The path forward for biofuels and biomaterials. science. 2006;311(5760):484-9.

[2] U.S. Department of Energy. U.S. Billion-Ton Update: Biomass Supply for a Bioenergy and Bioproducts Industry. In: Perlack RD, Stokes BJ, (Leads). editors. ORNL/TM-2011/224. Oak Ridge National Laboratory, Oak Ridge, TN. 2011. p. 227.

[3] Turhollow A, Perlack R, Eaton L, Langholtz M, Brandt C, Downing M, et al. The updated billion-ton resource assessment. Biomass Bioenerg. 2014;70:149-64.

[4] Somerville C. The billion-ton biofuels vision. Science. 2006;312(5778):1277-.

[5] Kenney KL, Smith WA, Gresham GL, Westover TL. Understanding biomass feedstock variability. Biofuels. 2013;4(1):111-27.

[6] Thompson DN, Campbell T, Bals B, Runge T, Teymouri F, Ovard LP. Chemical preconversion: application of low-severity pretreatment chemistries for commoditization of lignocellulosic feedstock. Biofuels. 2013;4(3):323-40.

[7] Jonsson L, Alriksson B, Nilvebrant N-O. Bioconversion of lignocellulose: inhibitors and detoxification. Biotechnol Biofuels. 2013;6(1):16.

[8] Carpenter D, Westover TL, Czernik S, Jablonski W. Biomass feedstocks for renewable fuel production: a review of the impacts of feedstock and pretreatment on the yield and product distribution of fast pyrolysis bio-oils and vapors. Green Chemistry. 2014;16(2):384-406.

[9] Tao L, Templeton DW, Humbird D, Aden A. Effect of corn stover compositional variability on minimum ethanol selling price (MESP). Bioresource Technol. 2013;140:426-30. 
[10] Chen XW, Shekiro J, Pschorn T, Sabourin M, Tao L, Elander R, et al. A highly efficient dilute alkali deacetylation and mechanical (disc) refining process for the conversion of renewable biomass to lower cost sugars. Biotechnol Biofuels. 2014;7.

[11] Hsu DD, Inman D, Heath GA, Wolfrum EJ, Mann MK, Aden A. Life Cycle Environmental Impacts of Selected US Ethanol Production and Use Pathways in 2022. Environ Sci Technol. 2010;44(13):5289-97.

[12] Bridgwater AV. Review of fast pyrolysis of biomass and product upgrading. Biomass Bioenerg. 2012;38:68-94.

[13] Carrier M, Joubert JE, Danje S, Hugo T, Gorgens J, Knoetze J. Impact of the lignocellulosic material on fast pyrolysis yields and product quality. Bioresource Technol. 2013;150:129-38. [14] Foust T, Aden A, Dutta A, Phillips S. An economic and environmental comparison of a biochemical and a thermochemical lignocellulosic ethanol conversion processes. Cellulose. 2009;16(4):547-65.

[15] Radlein D, Quignard A. A Short Historical Review of Fast Pyrolysis of Biomass. Oil Gas Sci Technol. 2013;68(4):765-83.

[16] Scott DS, Paterson L, Piskorz J, Radlein D. Pretreatment of poplar wood for fast pyrolysis: rate of cation removal. J Anal Appl Pyrol. 2001;57(2):169-76.

[17] Shi F, Wang P, Duan Y, Link D, Morreale B. Recent developments in the production of liquid fuels via catalytic conversion of microalgae: experiments and simulations. Rsc Adv. 2012;2(26):9727-47.

[18] Elliott DC, Biller P, Ross AB, Schmidt AJ, Jones SB. Hydrothermal liquefaction of biomass: Developments from batch to continuous process. Bioresource Technol. 2015;178(0):147-56. 
[19] Naik SN, Goud VV, Rout PK, Dalai AK. Production of first and second generation biofuels: A comprehensive review. Renew Sust Energ Rev. 2010;14(2):578-97.

[20] Kumar S, Gupta RB. Biocrude Production from Switchgrass Using Subcritical Water. Energ Fuel. 2009;23(10):5151-9.

[21] Bridgwater AV, Peacocke GVC. Fast pyrolysis processes for biomass. Renew Sust Energ Rev. 2000;4(1):1-73.

[22] Hognon C, Delrue F, Texier J, Grateau M, Thiery S, Miller H, et al. Comparison of pyrolysis and hydrothermal liquefaction of Chlamyclomonas reinharcltii. Growth studies on the recovered hydrothermal aqueous phase. Biomass Bioenerg. 2015;73:23-31.

[23] Pavlovic I, Knez Z, Skerget M. Hydrothermal Reactions of Agricultural and Food Processing Wastes in Sub- and Supercritical Water: A Review of Fundamentals, Mechanisms, and State of Research. J Agr Food Chem. 2013;61(34):8003-25.

[24] Lynd LR, van Zyl WH, McBride JE, Laser M. Consolidated bioprocessing of cellulosic biomass: an update. Curr Opin Biotech. 2005;16(5):577-83.

[25] Pu YQ, Hu F, Huang F, Davison BH, Ragauskas AJ. Assessing the molecular structure basis for biomass recalcitrance during dilute acid and hydrothermal pretreatments. Biotechnol Biofuels. 2013;6(1):15.

[26] Harmsen P. Literature Review of Physical and Chemical Pretreatment Processes for Lignocellulosic Biomass: Wageningen UR, Food \& Biobased Research; 2010.

[27] Li CL, Knierim B, Manisseri C, Arora R, Scheller HV, Auer M, et al. Comparison of dilute acid and ionic liquid pretreatment of switchgrass: Biomass recalcitrance, delignification and enzymatic saccharification. Bioresource Technol. 2010;101(13):4900-6. 
[28] Foston M, Ragauskas AJ. Changes in the Structure of the Cellulose Fiber Wall during Dilute Acid Pretreatment in Populus Studied by H-1 and H-2 NMR. Energ Fuel. 2010;24:567785.

[29] Zhao H, Kwak JH, Wang Y, Franz JA, White JM, Holladay JE. Effects of Crystallinity on Dilute Acid Hydrolysis of Cellulose by Cellulose Ball-Milling Study. Energ Fuel. 2006;20(2):807-11.

[30] Park S, Baker JO, Himmel ME, Parilla PA, Johnson DK. Cellulose crystallinity index: measurement techniques and their impact on interpreting cellulase performance. Biotechnol Biofuels. 2010;3.

[31] Chundawat SPS, Beckham GT, Himmel ME, Dale BE. Deconstruction of Lignocellulosic Biomass to Fuels and Chemicals. Annu Rev Chem Biomol. 2011;2:121-45.

[32] Kumar R, Mago G, Balan V, Wyman CE. Physical and chemical characterizations of corn stover and poplar solids resulting from leading pretreatment technologies. Bioresource Technol. 2009;100(17):3948-62.

[33] Hakansson H, Ahlgren P, Germgard U. The degree of disorder in hardwood kraft pulps studied by means of LODP. Cellulose. 2005;12(3):327-35.

[34] Cao SL, Pu YQ, Studer M, Wyman C, Ragauskas AJ. Chemical transformations of Populus trichocarpa during dilute acid pretreatment. Rsc Adv. 2012;2(29):10925-36.

[35] Alvira P, Tomás-Pejó E, Ballesteros M, Negro MJ. Pretreatment technologies for an efficient bioethanol production process based on enzymatic hydrolysis: A review. Bioresource Technol. 2010;101(13):4851-61. 
[36] Foston M, Ragauskas AJ. Changes in lignocellulosic supramolecular and ultrastructure during dilute acid pretreatment of Populus and switchgrass. Biomass and Bioenergy. 2010;34(12):1885-95.

[37] Pan XJ, Gilkes N, Saddler JN. Effect of acetyl groups on enzymatic hydrolysis of cellulosic substrates. Holzforschung. 2006;60(4):398-401.

[38] Chen X, Shekiro J, Franden MA, Wang W, Zhang M, Kuhn E, et al. The impacts of deacetylation prior to dilute acid pretreatment on the bioethanol process. Biotechnol Biofuels. 2012;5:8.

[39] Selig MJ, Adney WS, Himmel ME, Decker SR. The impact of cell wall acetylation on corn stover hydrolysis by cellulolytic and xylanolytic enzymes. Cellulose. 2009;16(4):711-22. [40] Selig MJ, Viamajala S, Decker SR, Tucker MP, Himmel ME, Vinzant TB. Deposition of lignin droplets produced during dilute acid pretreatment of maize stems retards enzymatic hydrolysis of cellulose. Biotechnology Progress. 2007;23(6):1333-9.

[41] Kumar R, Hu F, Sannigrahi P, Jung S, Ragauskas AJ, Wyman CE. Carbohydrate derivedpseudo-lignin can retard cellulose biological conversion. Biotechnol Bioeng. 2013;110(3):73753.

[42] Gao D, Haarmeyer C, Balan V, Whitehead T, Dale B, Chundawat S. Lignin triggers irreversible cellulase loss during pretreated lignocellulosic biomass saccharification. Biotechnol Biofuels. 2014;7(1):175.

[43] Studer MH, DeMartini JD, Davis MF, Sykes RW, Davison B, Keller M, et al. Lignin content in natural Populus variants affects sugar release. P Natl Acad Sci USA. 2011;108(15):6300-5. 
[44] Hu F, Jung S, Ragauskas A. Pseudo-lignin formation and its impact on enzymatic hydrolysis. Bioresource Technol. 2012;117:7-12.

[45] Li JB, Henriksson G, Gellerstedt G. Lignin depolymerization/repolymerization and its critical role for delignification of aspen wood by steam explosion. Bioresource Technol. 2007;98(16):3061-8.

[46] Sannigrahi P, Kim DH, Jung S, Ragauskas A. Pseudo-lignin and pretreatment chemistry. Energ Environ Sci. 2011;4(4):1306-10.

[47] Donohoe BS, Decker SR, Tucker MP, Himmel ME, Vinzant TB. Visualizing Lignin Coalescence and Migration Through Maize Cell Walls Following Thermochemical Pretreatment. Biotechnol Bioeng. 2008;101(5):913-25.

[48] Trajano HL, Engle NL, Foston M, Ragauskas AJ, Tschaplinski TJ, Wyman CE. The fate of lignin during hydrothermal pretreatment. Biotechnol Biofuels. 2013;6.

[49] Moxley G, Gaspar A, Higgins D, Xu H. Structural changes of corn stover lignin during acid pretreatment. Journal of Industrial Microbiology \& Biotechnology. 2012;39(9):1289-99. [50] Kim Y, Ximenes E, Mosier NS, Ladisch MR. Soluble inhibitors/deactivators of cellulase enzymes from lignocellulosic biomass. Enzyme and Microbial Technology. 2011;48(4-5):40815.

[51] Thy P, Yu CW, Jenkins BM, Lesher CE. Inorganic Composition and Environmental Impact of Biomass Feedstock. Energ Fuel. 2013;27(7):3969-87.

[52] Lacey JA, Emerson RM, Westover TL, Thompson DN. Ash reduction strategies in corn stover facilitated by anatomical and size fractionation. Biomass Bioenerg. 2015; Article in Review. 
[53] Subbarao GV, Ito O, Berry WL, Wheeler RM. Sodium - A functional plant nutrient. Crit Rev Plant Sci. 2003;22(5):391-416.

[54] Vassilev SV, Baxter D, Andersen LK, Vassileva CG. An overview of the composition and application of biomass ash. Part 1. Phase-mineral and chemical composition and classification. Fuel. 2013;105:40-76.

[55] Montross MD, Crofcheck CL. Effect of stover fraction and storage method on glucose production during enzymatic hydrolysis. Bioresource Technol. 2004;92(3):269-74.

[56] Saha BC, Iten LB, Cotta MA, Wu YV. Dilute Acid Pretreatment, Enzymatic

Saccharification, and Fermentation of Rice Hulls to Ethanol. Biotechnology Progress. 2005;21(3):816-22.

[57] Li ZY, Zhai HM, Zhang Y, Yu L. Cell morphology and chemical characteristics of corn stover fractions. Ind Crop Prod. 2012;37(1):130-6.

[58] Pecora AAB, Avila I, Lira CS, Cruz G, Crnkovic PM. Prediction of the combustion process in fluidized bed based on physical-chemical properties of biomass particles and their hydrodynamic behaviors. Fuel Process Technol. 2014;124:188-97.

[59] Sun N, Xu F, Sathitsuksanoh N, Thompson VS, Cafferty K, Li C, et al. Blending municipal solid waste with corn stover for sugar production using ionic liquid process. Bioresource Technol. 2015;186:200-6.

[60] Tucker MP, Kim KH, Newman MM, Nguyen QA. Effects of temperature and moisture on dilute-acid steam explosion pretreatment of corn stover and cellulase enzyme digestibility. Biotechnology for Fuels and Chemicals: Springer; 2003. p. 165-77. 
[61] Weiss ND, Farmer JD, Schell DJ. Impact of corn stover composition on hemicellulose conversion during dilute acid pretreatment and enzymatic cellulose digestibility of the pretreated solids. Bioresource Technol. 2010;101(2):674-8.

[62] Zha Y, Westerhuis J, Muilwijk B, Overkamp K, Nijmeijer B, Coulier L, et al. Identifying inhibitory compounds in lignocellulosic biomass hydrolysates using an exometabolomics approach. BMC Biotechnology. 2014;14(1):22.

[63] Palmqvist E, Hahn-Hägerdal B. Fermentation of lignocellulosic hydrolysates. I: inhibition and detoxification. Bioresource Technol. 2000;74(1):17-24.

[64] Palmqvist E, Hahn-Hägerdal B. Fermentation of lignocellulosic hydrolysates. II: inhibitors and mechanisms of inhibition. Bioresource Technol. 2000;74(1):25-33.

[65] Casey E, Sedlak M, Ho NWY, Mosier NS. Effect of acetic acid and pH on the cofermentation of glucose and xylose to ethanol by a genetically engineered strain of Saccharomyces cerevisiae. FEMS yeast research. 2010;10(4):385-93.

[66] Russell JB. Another explanation for the toxicity of fermentation acids at low $\mathrm{pH}$ : anion accumulation versus uncoupling. Journal of Applied Bacteriology. 1992;73(5):363-70. [67] Agblevor FA, Fu J, Hames B, McMillan JD. Identification of microbial inhibitory functional groups in corn stover hydrolysate by carbon-13 nuclear magnetic resonance spectroscopy. Appl Biochem Biotech. 2004;119(2):97-120.

[68] Feng Y, Qi X, Jian HL, Sun RC, Jiang JX. Effect of Inhibitors on Enzymatic Hydrolysis and Simultaneous Saccharification Fermentation for Lactic Acid Production from Steam Explosion Pretreated Lespedeza Stalks. Bioresources. 2012;7(3):3755-66.

[69] Luo C, Brink DL, Blanch HW. Identification of potential fermentation inhibitors in conversion of hybrid poplar hydrolyzate to ethanol. Biomass and Bioenergy. 2002;22(2):125-38. 
[70] Persson P, Andersson J, Gorton L, Larsson S, Nilvebrant N-O, Jönsson LJ. Effect of Different Forms of Alkali Treatment on Specific Fermentation Inhibitors and on the Fermentability of Lignocellulose Hydrolysates for Production of Fuel Ethanol. J Agr Food Chem. 2002;50(19):5318-25.

[71] Mohagheghi A, Ruth M, Schell DJ. Conditioning hemicellulose hydrolysates for fermentation: Effects of overliming $\mathrm{pH}$ on sugar and ethanol yields. Process Biochem. 2006;41(8):1806-11.

[72] Ranatunga TD, Jervis J, Helm RF, McMillan JD, Wooley RJ. The effect of overliming on the toxicity of dilute acid pretreated lignocellulosics: the role of inorganics, uronic acids and ether-soluble organics. Enzyme and Microbial Technology. 2000;27(3-5):240-7.

[73] Cruz JM, Domínguez JM, Domínguez H, Parajó JC. Solvent extraction of hemicellulosic wood hydrolysates: a procedure useful for obtaining both detoxified fermentation media and polyphenols with antioxidant activity. Food chemistry. 1999;67(2):147-53.

[74] Mussatto SI, Roberto IC. Alternatives for detoxification of diluted-acid lignocellulosic hydrolyzates for use in fermentative processes: a review. Bioresource Technol. 2004;93(1):1-10. [75] Palmqvist E, Hahn-Hägerdal B, Szengyel Z, Zacchi G, Rèczey K. Simultaneous detoxification and enzyme production of hemicellulose hydrolysates obtained after steam pretreatment. Enzyme and microbial technology. 1997;20(4):286-93.

[76] Canilha L, Chandel AK, Suzane dos Santos Milessi T, Antunes FA, \#xf4, Fernandes n, et al. Bioconversion of Sugarcane Biomass into Ethanol: An Overview about Composition, Pretreatment Methods, Detoxification of Hydrolysates, Enzymatic Saccharification, and Ethanol Fermentation. Journal of Biomedicine and Biotechnology. 2012;2012:15. 
[77] Jönsson L, Palmqvist E, Nilvebrant N-O, Hahn-Hägerdal B. Detoxification of wood hydrolysates with laccase and peroxidase from the white-rot fungus Trametes versicolor. Applied microbiology and biotechnology. 1998;49(6):691-7.

[78] A.K. C, S.S. dS, O.V. S. Detoxification of Lignocellulosic Hydrolysates for Improved Bioethanol Production. In: Bernardes MADS, editor. Biofuel Production-Recent Developments and Prospects: InTech; 2011.

[79] Larsson S, Cassland P, Jonsson LJ. Development of a Saccharomyces cerevisiae strain with enhanced resistance to phenolic fermentation inhibitors in lignocellulose hydrolysates by heterologous expression of laccase. Appl Environ Microb. 2001;67(3):1163-70.

[80] Alriksson B, Horvath IS, Jonsson LJ. Overexpression of Saccharomyces cerevisiae transcription factor and multidrug resistance genes conveys enhanced resistance to lignocellulose-derived fermentation inhibitors. Process Biochem. 2010;45(2):264-71.

[81] Hasunuma T, Sung K, Sanda T, Yoshimura K, Matsuda F, Kondo A. Efficient fermentation of xylose to ethanol at high formic acid concentrations by metabolically engineered Saccharomyces cerevisiae. Applied microbiology and biotechnology. 2011;90(3):997-1004. [82] Casey E, Mosier NS, Adamec J, Stockdale Z, Ho N, Sedlak M. Effect of salts on the Cofermentation of glucose and xylose by a genetically engineered strain of Saccharomyces cerevisiae. Biotechnol Biofuels. 2013;6.

[83] Bautista-Gallego J, Arroyo-Lopez FN, Duran-Quintana MC, Garrido-Fernandez A. Individual effects of sodium, potassium, calcium, and magnesium chloride salts on Lactobacillus pentiosus and Saccharomyces cerevisiae growth. J Food Protect. 2008;71(7):1412-21. [84] Garcia MJ, Rios G, Ali R, Belles JM, Serrano R. Comparative physiology of salt tolerance in Candida tropicalis and Saccharomyces cerevisiae. Microbiology. 1997;143 ( Pt 4):1125-31. 
[85] Maiorella BL, Blanch HW, Wilke CR. Feed Component Inhibition in Ethanolic Fermentation by Saccharomyces-Cerevisiae. Biotechnol Bioeng. 1984;26(10):1155-66.

[86] Wilkie AC, Riedesel KJ, Owens JM. Stillage characterization and anaerobic treatment of ethanol stillage from conventional and cellulosic feedstocks. Biomass and Bioenergy. 2000;19(2):63-102.

[87] Xie J, Weng Q, Ye GY, Luo SS, Zhu R, Zhang AP, et al. Bioethanol Production from Sugarcane Grown in Heavy Metal-Contaminated Soils. Bioresources. 2014;9(2):2509-20. [88] Biddy M, Dutta A, Jones S, Meyer A. Ex-situ catalytic fast pyrolysis technology pathway. Pacific Northwest National Laboratory, Richland, WA http://www pnl gov/main/publications/external/technical_reports/PNNL-22317 pdf. 2013.

[89] Ruddy DA, Schaidle JA, Ferrell Iii JR, Wang J, Moens L, Hensley JE. Recent advances in heterogeneous catalysts for bio-oil upgrading via "ex situ catalytic fast pyrolysis": catalyst development through the study of model compounds. Green Chemistry. 2014;16(2):454-90. [90] Wan S, Wang Y. A review on ex situ catalytic fast pyrolysis of biomass. Front Chem Sci Eng. 2014;8(3):280-94.

[91] Mullen CA, Boateng AA, Goldberg NM, Lima IM, Laird DA, Hicks KB. Bio-oil and biochar production from corn cobs and stover by fast pyrolysis. Biomass Bioenerg. 2010;34(1):6774.

[92] Mohan D, Pittman CU, Steele PH. Pyrolysis of wood/biomass for bio-oil: A critical review. Energ Fuel. 2006;20(3):848-89.

[93] Antal MJ. Effects of reactor severity on the gas-phase pyrolysis of cellulose- and kraft lignin-derived volatile matter. Industrial \& Engineering Chemistry Product Research and Development. 1983;22(2):366-75. 
[94] Liden AG, Berruti F, Scott DS. A KINETIC MODEL FOR THE PRODUCTION OF LIQUIDS FROM THE FLASH PYROLYSIS OF BIOMASS. Chemical Engineering Communications. 1988;65(1):207-21.

[95] Patwardhan PR, Satrio JA, Brown RC, Shanks BH. Influence of inorganic salts on the primary pyrolysis products of cellulose. Bioresource Technol. 2010;101(12):4646-55.

[96] Mourant D, Wang Z, He M, Wang XS, Garcia-Perez M, Ling K, et al. Mallee wood fast pyrolysis: Effects of alkali and alkaline earth metallic species on the yield and composition of bio-oil. Fuel. 2011;90(9):2915-22.

[97] Bridgwater AV. Principles and practice of biomass fast pyrolysis processes for liquids. J Anal Appl Pyrol. 1999;51(1-2):3-22.

[98] Bulushev DA, Ross JR. Catalysis for conversion of biomass to fuels via pyrolysis and gasification: a review. Catalysis Today. 2011;171(1):1-13.

[99] Shimada N, Kawamoto H, Saka S. Different action of alkali/alkaline earth metal chlorides on cellulose pyrolysis. J Anal Appl Pyrol. 2008;81(1):80-7.

[100] Atadana FW. Catalytic Pyrolysis of Cellulose, Hemicellulose and Lignin Model Compounds. 2010.

[101] Obernberger I, Biedermann F. Fractionated Heavy Metal Separation in Biomass Combustion Plants as a Primary Measure for a Sustainable Ash Utilization. In: Bridgwater AV, Boocock DGB, editors. Developments in Thermochemical Biomass Conversion: Springer Netherlands; 1997. p. 1368-83.

[102] Dayton D. The Fate of Alkali Metal during Biomass Thermochemical Conversion. In: Bridgwater AV, Boocock DGB, editors. Developments in Thermochemical Biomass Conversion: Springer Netherlands; 1997. p. 1263-77. 
[103] Olsson JG, Jäglid U, Pettersson JBC, Hald P. Alkali Metal Emission during Pyrolysis of Biomass. Energ Fuel. 1997;11(4):779-84.

[104] Gunawardena DA, Fernando SD. Methods and Applications of Deoxygenation for the Conversion of Biomass to Petrochemical Products. Natural gas. 2013;16:20.90.

[105] Zhang Y, Kajitani S, Ashizawa M, Oki Y. Tar destruction and coke formation during rapid pyrolysis and gasification of biomass in a drop-tube furnace. Fuel. 2010;89(2):302-9.

[106] Bulatov I, Klemeš J. Towards cleaner technologies: emissions reduction, energy and waste minimisation, industrial implementation. Clean Technologies and Environmental Policy. 2009;11(1):1-6.

[107] Mezerette C, Girard P. Environmental aspects of gaseous emissions from wood carbonisation and pyrolysis processes. Biomass Pyrolysis Liquids Upgrading and Utilization: Springer; 1991. p. 263-87.

[108] Chen H, Namioka T, Yoshikawa K. Characteristics of tar, NOx precursors and their absorption performance with different scrubbing solvents during the pyrolysis of sewage sludge. Appl Energ. 2011;88(12):5032-41.

[109] He M, Xiao B, Liu S, Hu Z, Guo X, Luo S, et al. Syngas production from pyrolysis of municipal solid waste (MSW) with dolomite as downstream catalysts. J Anal Appl Pyrol. 2010;87(2):181-7.

[110] Agblevor FA, Besler S. Inorganic Compounds in Biomass Feedstocks. 1. Effect on the Quality of Fast Pyrolysis Oils. Energ Fuel. 1996;10(2):293-8.

[111] Ramirez JA, Brown RJ, Rainey TJ. A Review of Hydrothermal Liquefaction Bio-Crude Properties and Prospects for Upgrading to Transportation Fuels. Energies. 2015;8(7):6765-94. 
[112] Akhtar J, Amin NAS. A review on process conditions for optimum bio-oil yield in hydrothermal liquefaction of biomass. Renew Sust Energ Rev. 2011;15(3):1615-24.

[113] Toor SS, Rosendahl L, Rudolf A. Hydrothermal liquefaction of biomass: A review of subcritical water technologies. Energy. 2011;36(5):2328-42.

[114] Tian CY, Li BM, Liu ZD, Zhang YH, Lu HF. Hydrothermal liquefaction for algal biorefinery: A critical review. Renew Sust Energ Rev. 2014;38:933-50.

[115] Vamvuka D, Pitharoulis M, Alevizos G, Repouskou E, Pentari D. Ash effects during combustion of lignite/biomass blends in fluidized bed. Renewable Energy. 2009;34(12):2662-71. [116] Feng SH, Yuan ZS, Leitch M, Xu CC. Hydrothermal liquefaction of barks into bio-crude Effects of species and ash content/composition. Fuel. 2014;116:214-20.

[117] Peterson AA, Vogel F, Lachance RP, Froling M, Antal MJ, Tester JW. Thermochemical biofuel production in hydrothermal media: A review of sub- and supercritical water technologies. Energ Environ Sci. 2008;1(1):32-65.

[118] Guo Y, Yeh T, Song WH, Xu DH, Wang SZ. A review of bio-oil production from hydrothermal liquefaction of algae. Renew Sust Energ Rev. 2015;48:776-90.

[119] Tumuluru JS, Hess JR, Boardman RD, Wright CT, Westover TL. Formulation, pretreatment, and densification options to improve biomass specifications for co-firing high percentages with coal. Industrial Biotechnology. 2012;8(3):113-32.

[120] Lamers P, Roni MS, Tumuluru JS, Jacobson JJ, Cafferty KG, Hansen JK, et al. Technoeconomic analysis of decentralized biomass processing depots. Bioresource Technol. 2015;194:205-13.

[121] Sokhansanj S, Hess JR. Biomass supply logistics and infrastructure. Biofuels: Springer; 2009. p. 1-25. 
[122] Dale BE, Ong RG. Design, implementation, and evaluation of sustainable bioenergy production systems. Biofuels, Bioproducts and Biorefining. 2014;8(4):487-503.

[123] Lacey JA, Aston JE, Westover TL, Cherry RS, Thompson DN. Removal of introduced inorganic content from chipped forest residues via air classification. Fuel. 2015; Article in Review.

[124] Deng L, Zhang T, Che DF. Effect of water washing on fuel properties, pyrolysis and combustion characteristics, and ash fusibility of biomass. Fuel Process Technol. 2013;106:71220.

[125] Liu X, Bi XT. Removal of inorganic constituents from pine barks and switchgrass. Fuel Process Technol. 2011;92(7):1273-9.

[126] Chen XW, Shekiro J, Elander R, Tucker M. Improved Xylan Hydrolysis of Corn Stover by Deacetylation with High Solids Dilute Acid Pretreatment. Ind Eng Chem Res. 2012;51(1):70-6. [127] Essig M, Lowary T, Richards GN, Schenck E. Influences of "Neutral” Salts on Thermochemical Conversion of Cellulose and of Sucrose. In: Bridgwater AV, Kuester JL, editors. Research in Thermochemical Biomass Conversion: Springer Netherlands; 1988. p. 14354.

[128] Mayer ZA, Apfelbacher A, Hornung A. A comparative study on the pyrolysis of metaland ash-enriched wood and the combustion properties of the gained char. J Anal Appl Pyrol. 2012;96(0):196-202.

[129] Wright MM, Daugaard DE, Satrio JA, Brown RC. Techno-economic analysis of biomass fast pyrolysis to transportation fuels. Fuel. 2010;89, Supplement 1(0):S2-S10.

[130] Fahmi R, Bridgwater A, Donnison I, Yates N, Jones JM. The effect of lignin and inorganic species in biomass on pyrolysis oil yields, quality and stability. Fuel. 2008;87(7):1230-40. 
[131] Thompson D, Shaw P, Lacey J. Post-Harvest Processing Methods for Reduction of Silica and Alkali Metals in Wheat Straw. In: Davison B, Lee J, Finkelstein M, McMillan J, editors. Biotechnology for Fuels and Chemicals: Humana Press; 2003. p. 205-18.

[132] Fahmi R, Bridgwater AV, Darvell LI, Jones JM, Yates N, Thain S, et al. The effect of alkali metals on combustion and pyrolysis of Lolium and Festuca grasses, switchgrass and willow. Fuel. 2007;86(10-11):1560-9.

[133] Li D, Chen L, Xu D, Zhang X, Ye N, Chen F, et al. Preparation and characteristics of biooil from the marine brown alga Sargassum patens C. Agardh. Bioresource Technol. $2012 ; 104: 737-42$.

[134] Chen W-T, Zhang Y, Zhang J, Yu G, Schideman LC, Zhang P, et al. Hydrothermal liquefaction of mixed-culture algal biomass from wastewater treatment system into bio-crude oil. Bioresource Technol. 2014;152:130-9.

[135] Demirbaş A. Mechanisms of liquefaction and pyrolysis reactions of biomass. Energy Conversion and Management. 2000;41(6):633-46. 


\section{Figure Captions}

2 Figure 1. Feedstock quality drives selection of supply, logistics and conversion process.

3 Figure 2. Three major conversion pathways for converting biomass into biofuels [8, 17-19]. 


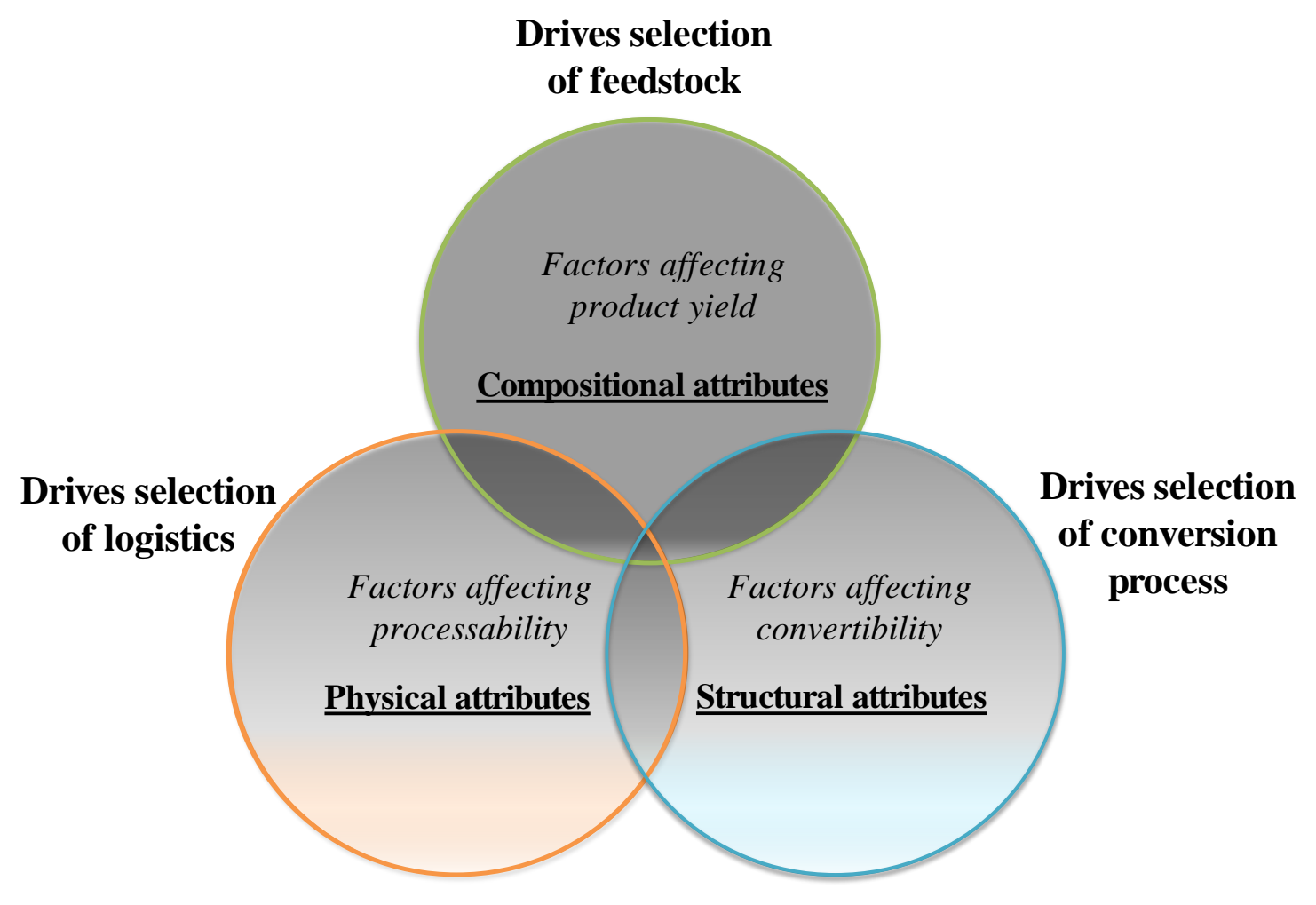




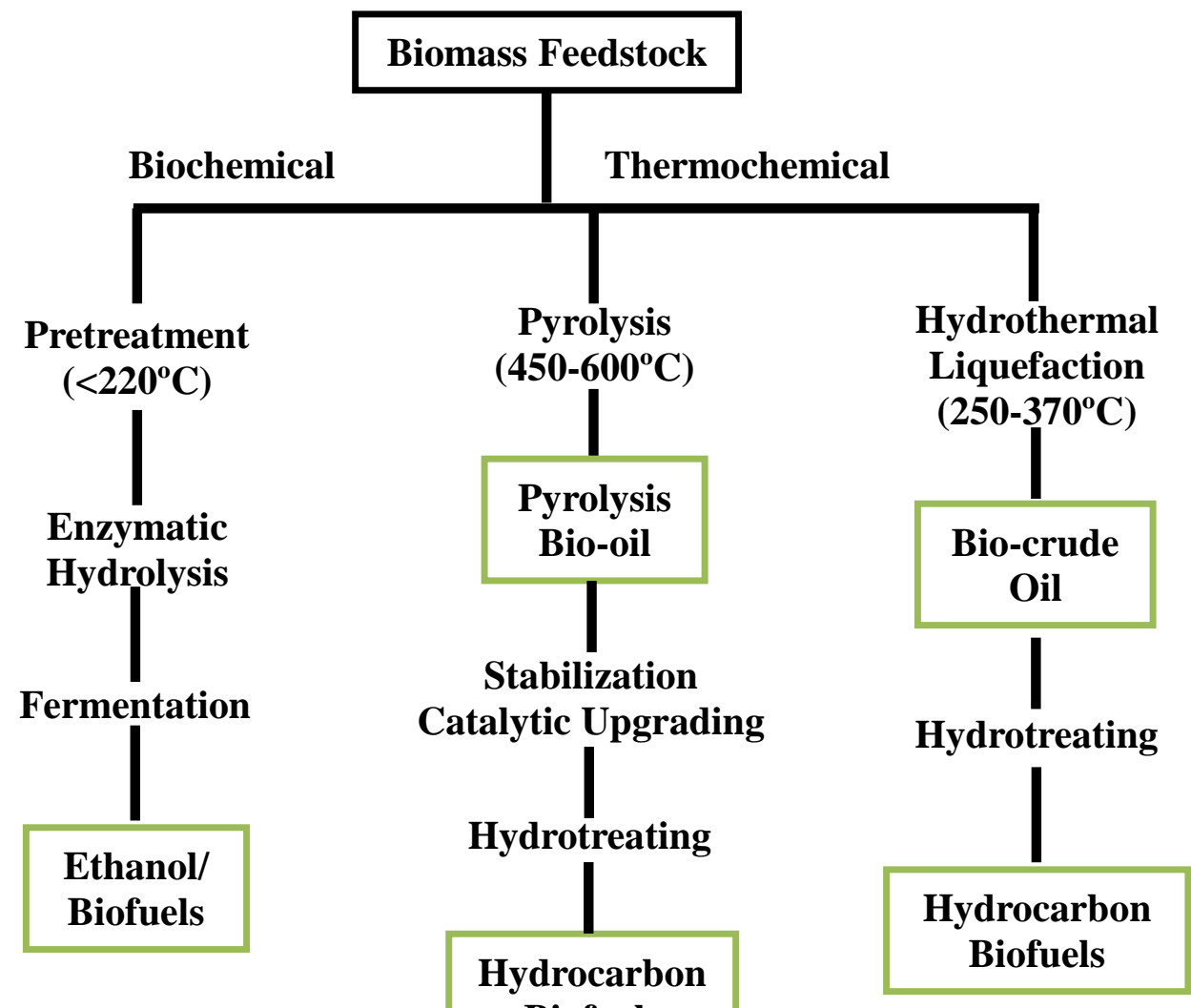

27 Figure 2. Three major conversion pathways for converting biomass into biofuels [8, 17-20]. 
Table 1. Key feedstock quality specifications and their major impact

\begin{tabular}{|c|c|c|}
\hline \multicolumn{2}{|c|}{ Feedstock quality specifications } & \multirow{2}{*}{$\begin{array}{l}\text { Impact } \\
\text { - } \quad \text { Conversion efficiency } \\
\text { - Transportation economics }\end{array}$} \\
\hline \multirow{7}{*}{$\begin{array}{l}\text { Physical } \\
\text { Attributes } \\
\text { (macroscale) }\end{array}$} & Feedstock type & \\
\hline & Particle size and shape & $\begin{array}{ll} & \text { Material handling } \\
\text { - } & \text { Conversion efficiency } \\
\end{array}$ \\
\hline & Moisture content & $\begin{array}{ll}\text { - } & \text { Drying, grinding, feeding and handling } \\
& \text { efficiency } \\
\text { - } & \text { Conversion efficiency } \\
\text { - } & \text { Aerobic storage stability } \\
\end{array}$ \\
\hline & Energy density & $\begin{array}{ll} & \text { Thermochemical conversion efficiency } \\
\text { - } & \text { Storage and transportation economics }\end{array}$ \\
\hline & Bulk density & $\begin{array}{ll}\text { - } & \text { Feeding and handling efficiency } \\
\text { - } & \text { Storage and transportation economics }\end{array}$ \\
\hline & Hygroscopicity & $\begin{array}{ll} & \text { Aerobic storage stability } \\
\text { - } & \text { Drying cost } \\
\end{array}$ \\
\hline & Flowability & - $\quad$ Feeding, pumping and discharging \\
\hline \multirow{4}{*}{$\begin{array}{l}\text { Structural } \\
\text { Attributes } \\
\text { (microscale) }\end{array}$} & Cellulose crystallinity & $\begin{array}{l}\text { - Biomass recalcitrance and conversion } \\
\text { efficiency }\end{array}$ \\
\hline & Biomass porosity & $\begin{array}{l}\text { - Biomass recalcitrance and conversion } \\
\text { efficiency }\end{array}$ \\
\hline & Degree of polymerization & $\begin{array}{ll}\text { - } & \text { Biomass recalcitrance and conversion } \\
\text { efficiency }\end{array}$ \\
\hline & Surface area & $\begin{array}{l}\text { - Biomass recalcitrance and conversion } \\
\text { efficiency }\end{array}$ \\
\hline \multirow{5}{*}{$\begin{array}{l}\text { Compositional } \\
\text { Attributes } \\
\text { (molecular scale) }\end{array}$} & Structural carbohydrate & - Conversion yield \\
\hline & Lignin & $\begin{array}{ll}- & \text { Conversion yield } \\
- & \text { Conversion efficiency } \\
\text { - } & \text { Energy density } \\
\end{array}$ \\
\hline & Ash & $\begin{array}{ll}- & \text { Conversion efficiency } \\
\text { - } & \text { Equipment wear } \\
\text { - } & \text { Waste handling } \\
\end{array}$ \\
\hline & Elemental content & - Conversion efficiency \\
\hline & Inhibitors & $\begin{array}{ll}\text { - } & \text { Toxic or inhibitory } \\
\text { - } & \text { Conversion efficiency } \\
\end{array}$ \\
\hline
\end{tabular}




\section{Table 2. Feedstock compositional properties and their impacts on pretreatment and hydrolysis}

\begin{tabular}{|c|c|c|}
\hline Chemical Property & Impact on pretreatment and hydrolysis & Reference \\
\hline Cellulose crystallinity & $\begin{array}{l}\text { Affect biomass recalcitrance, pretreatment severity, enzyme usage and operation costs. Negative effect } \\
\text { on cellulose digestibility and sugar yield. }\end{array}$ & {$[25-31,36]$} \\
\hline Cellulose DP & $\begin{array}{l}\text { High DP with less cellulose reducing end contributes to the biomass recalcitrance. Reduction of DP } \\
\text { relies highly on pretreatment severity and enzyme usage. }\end{array}$ & {$[25,26,28,32-36]$} \\
\hline Acetyl group & $\begin{array}{l}\text { Increase biomass recalcitrance. Retard cellulase accessibility and inhibit productive binding to } \\
\text { cellulose. } \\
\text { Pretreatment generates in-situ source of acetic acid, cause enzyme inhibition and sugar yield reduction. }\end{array}$ & {$[7,14,25,37-39]$} \\
\hline Lignin content & $\begin{array}{l}\text { Affect biomass recalcitrance, pretreatment severity, enzyme activity, sugar yield and operation cost. } \\
\text { Lignin triggers irreversible cellulase loss, requiring reduced or modified lignin content, or engineering } \\
\text { low-lignin binding enzymes to facilitate enzyme recycling. }\end{array}$ & {$[25,27,41-47]$} \\
\hline $\begin{array}{l}\text { Acid soluble lignin } \\
\text { content }\end{array}$ & $\begin{array}{l}\text { Re-condensation reactions decrease the delignification efficiency, prevent enzyme access, reduce the } \\
\text { lignin and sugar extractability. Lignin fragmentation and condensate depends on the pretreatment } \\
\text { conditions and severity, requires process optimization and fast heating/cooling reactors to improve the } \\
\text { efficiency. }\end{array}$ & {$[40-42,47]$} \\
\hline Lignin structure & $\begin{array}{l}\text { Syringyl/guaiacyl (S/G) structural alteration affects recalcitrance, pretreatment severity, and sugar } \\
\text { release. }\end{array}$ & {$[25,26,49,50]$} \\
\hline $\begin{array}{l}\text { Lignin-carbohydrate } \\
\text { complex linkages }\end{array}$ & $\begin{array}{l}\text { Contributes to biomass recalcitrance. Require acidic pretreatment to cause cleavage of linkages } \\
\text { between lignin and hemicellulose to facilitate hemicellulose dissolution, and increase pore volume and } \\
\text { surface area of cellulose for digestibility. }\end{array}$ & {$[25,26]$} \\
\hline Ash & Not fully clarified. Require solid/liquid separation and disposal with additional costs. & {$[56,60,61]$} \\
\hline
\end{tabular}


Table 3. Hydrolysate characteristics and their impacts on microbial fermentation of representative microorganism $S$.

\section{cerevisiae}

\begin{tabular}{|c|c|c|}
\hline Inhibitors & Impact on microbial fermentation & Reference \\
\hline \multirow[t]{2}{*}{ Acetic acid } & $\begin{array}{l}\text { Most abundant inhibitor to microorganisms. Affect the ethanol yield. Require conditioning process } \\
\text { with additional cost. }\end{array}$ & {$[7,14,62-66]$} \\
\hline & $\begin{array}{l}\text { Interact antagonistically with other inhibitors such as formic acid, levulinic acid, furfural and HMF, } \\
\text { and lead to increased inhibition. }\end{array}$ & {$[7,63]$} \\
\hline $\begin{array}{l}\text { Phenolic compounds, aromatic } \\
\text { compounds }\end{array}$ & $\begin{array}{l}\text { Highly inhibitory with low molecular weight phenolic compounds most toxic. Partition into } \\
\text { biological membranes, cause loss of integrity and affect cell growth. Requiring detoxification step } \\
\text { and recovery process as solid fuels or co-products. }\end{array}$ & {$[7,63,64,67]$} \\
\hline Salts and ionic compounds & $\begin{array}{l}\text { Inhibit cell growth and sugar consumptions, ethanol productivities, not significantly ethanol yields } \\
\text { but requiring long fermentation time instead which is not economic for industrial ethanol } \\
\text { production. Affecting more strongly on xylose consumption than glucose consumption. Lead to } \\
\text { osmotic stress that yeast will take energy and carbon to combat, induce and increase metabolic flux } \\
\text { to glycerol production. Require salts tolerant organisms, or optimized detoxification/fermentation } \\
\text { process. } \\
\mathrm{CaCl}_{2},\left(\mathrm{NH}_{4}\right)_{2} \mathrm{SO}_{4}>\mathrm{NaCl}, \mathrm{NH}_{4} \mathrm{Cl}>\mathrm{KH}_{2} \mathrm{PO}_{4}>\mathrm{MgCl}_{2}>\mathrm{MgSO}_{4}>\mathrm{KCl} \text {. }\end{array}$ & {$[7,9,82-85]$} \\
\hline Sodium & Toxic to yeast. High inhibition. Reduce xylose consumption and ethanol volumetric productivity . & [83] \\
\hline Potassium & $\begin{array}{l}\text { Less inhibitory than sodium and ammonium cations }(\mathrm{Na}>\mathrm{NH} 4>\mathrm{K}) . \mathrm{KCl}>\mathrm{K}_{2} \mathrm{SO}_{4} \text {. Chemicals that } \\
\text { generate potassium salts can replace those produce sodium or ammonium salts in fermentation. }\end{array}$ & [82] \\
\hline $\mathrm{Na}^{+} / \mathrm{K}^{+}$ & Low is preferred. Toxic when it is high. & [84] \\
\hline Ammonium & $\mathrm{NH}_{4} \mathrm{Cl},\left(\mathrm{NH}_{4}\right)_{2} \mathrm{SO}_{4}>0.2 \mathrm{M}$ inhibit the glucose consumption. & [82] \\
\hline Lithium & Much more toxic than sodium. $0.2 \mathrm{M}$ can reduce the relative cell growth to $2 \%$. & {$[84]$} \\
\hline Chloride & Cations $>$ anions, chloride $>$ sulfate. & {$[82-84]$} \\
\hline Sulfate & $\mathrm{Na}_{2} \mathrm{SO}_{4}, \mathrm{~K}_{2} \mathrm{SO}_{4}>0.2 \mathrm{M}$ inhibit the glucose consumption. & [82] \\
\hline $\mathrm{NaCl}$ & All chloride salts exert a significant antimicrobial effect on the growth cycle. Lower the water & [83] \\
\hline
\end{tabular}


activity, increase the ionic strength of the solution, and reduce the solubility of oxygen in water. For S. cerevisiae growth, NIC $31 \mathrm{~g} / \mathrm{L}(0.78 \mathrm{M})$, MIC $122 \mathrm{~g} / \mathrm{L}(3.05 \mathrm{M})$. wider range.

$\mathrm{CaCl}_{2}$

$\mathrm{MgCl}_{2}$

Inorganic salts, acetic acid and sugar degradation products Similar effect to NaCl. For S. cerevisiae growth, NIC 36 g/L (0.32M), MIC 124 g/L (1.12 M). Progressively less inhibitory. For $S$. cerevisiae growth, NIC 105 g/L (1.10 M), MIC 354 g/L (3.72 $\mathrm{M})$, wider range.

Dominant toxicity contributors to microbial growth and product yield depending on concentration. Additional detoxification will improve the cost. 
Table 4. Effect of feedstock chemical characteristics on pyrolysis and upgrading

\begin{tabular}{|c|c|c|}
\hline $\begin{array}{l}\text { Chemical } \\
\text { properties }\end{array}$ & Impact on pyrolysis and upgrading & Reference \\
\hline Hemicellulose & $\begin{array}{l}\text { Degrade mainly into acids and gases during fast pyrolysis. Organic acids formation causes corrosion of } \\
\text { vessels and pipework. Affect the production of pyrolytic water, impact the production of bio-oil organics. } \\
\text { Impact the activity energy under fast heating conditions. Limit the devolatilization of inorganics, improve } \\
\text { char formation. }\end{array}$ & {$[12,13,91,92]$} \\
\hline \multirow[t]{2}{*}{ Ash/ash composition } & $\begin{array}{l}\text { Affect pyrolysis oil yields; increase the pretreatment, conversion and transportation costs. Traces quantities } \\
\text { can affect the product quality, composition and rates of pyrolysis. Ash compositions affect char composition } \\
\text { and disposal. Require washing to remove ash, increase the unit operations and the associated cost. Soluble } \\
\text { ash affects acidity/quality. }\end{array}$ & $\begin{array}{l}{[8,12,16,93,} \\
127-129]\end{array}$ \\
\hline & $\begin{array}{l}\text { Upgrading: catalytic effect on vapor cracking. Cause phase separation, poor mixing. Difficulty in handling, } \\
\text { storage and processing. }\end{array}$ & $\begin{array}{l}{[12,21,93,130,} \\
131] .\end{array}$ \\
\hline \multirow[t]{3}{*}{ Total alkali metals } & $\begin{array}{l}\text { Pyrolysis: affect the conversion pathway, product distribution and bio-oil yields. Increase lignin degradation } \\
\text { and char production. Exist in pyrolysis vapor and require upstream scrubbing system or a guard bed of } \\
\text { catalyst prior to the upgrading reactor, with added cost, to reduce the deactivation and coke formation. }\end{array}$ & $\begin{array}{l}{[16,92,94,96,} \\
132]\end{array}$ \\
\hline & Upgrading: small concentrations can catalyze significant chemical changes during storage and upgrading. & {$[1,12,21,89,92$, } \\
\hline & $\begin{array}{l}\text { Can deposit on the catalyst surface, poisoning active sites, cause deactivation. Cause deposition of solids, } \\
\text { slag formation, erosion and corrosion to boilers, engine and turbines. Require hot vapor filtration, additional } \\
\text { oil processing, or feedstock pretreatment to remove alkali metals. Increase the processing cost. }\end{array}$ & $\begin{array}{l}98,102,103,110, \\
132] .\end{array}$ \\
\hline Silica & $\begin{array}{l}\text { Secondary catalyst for the cracking of large polymeric molecules such as oxygenates. Catalytic effect for } \\
\text { char formation and gas production, negative effect on bio-oil yields. Accumulate in char fraction. }\end{array}$ & {$[8,13,98]$} \\
\hline \multirow[t]{2}{*}{ Potassium } & $\begin{array}{l}\text { Pyrolysis: affect degradation pathway. Induce high char and low tar yields. Strong catalytic effect for } \\
\text { thermal degradation of lignin. Cause fragmentation of the monomers making up the natural polymer chains } \\
\text { rather than the predominant depolymerization that occurs in their absence. }\end{array}$ & $\begin{array}{l}{[8,16,51,92,95,} \\
96]\end{array}$ \\
\hline & Upgrading: most active natural catalysts, cause secondary cracking of vapors and reducing liquid yield and & {$[12]$} \\
\hline
\end{tabular}


Sodium

\section{Calcium}

Magnesium

Iron

Sulfur

Chlorine

Nitrogen

Char liquid quality. Can be more severe than char cracking.

Catalytic effect for thermal degradation of lignin to increase the yield of reaction water. A few ppm of sodium salts can highly increase char yield. Less active than potassium, cause secondary cracking of vapors and reducing liquid yield (lower levoglucosan production) and liquid quality. Can be more severe than char cracking.

Lesser catalytic effect for thermal degradation of lignin. Induce high char and low tar yields.

$[8,15,51,95]$

$[8,15,51,95]$

$[8,15,51]$

Catalyze the cellulose degradation to both leovoglucosan and levoglucosenone.

Corrosion generally. Detrimental poisons to upgrading catalysts. Need sulfur tolerant catalysts or sulfur sorbents for in-line removal. Formation of $\mathrm{H}_{2} \mathrm{~S}$ in pyrolysis vapor inhibits deoxygenation reactions on catalyst. Formation of $\mathrm{SO}_{2}$ requires scrubbing system to prevent harmful emission.

Corrosion generally. Iron or copper chlorides increase levoglucosan yields. Catalyst poisoning. $\mathrm{HCl}$ in the pyrolysis vapor is corrosive. Corrosion of boiler surface depending upon concentration and form of $\mathrm{Cl}$. Slag formation resulting from reactions of $\mathrm{Cl}$ with alkali metals such as $\mathrm{K}$ and $\mathrm{Na}$. $\mathrm{KCl}$ is the most prevalent compound deposited on heat transfer surfaces on combustion.

Strong catalytic effect, increased char, promotes different, simplified product distribution than alkali metals. Catalyst poisoning. Phosphate deposits at the front of catalyst bed by catalysis from alkali metals. Without alkali, formation of phosphoric acid accelerates the rate of coke deposition.

Unpleasant smell and NOx in combustion.

$[12,104-106]$

Catalytic effect on vapor cracking, require rapid removal. Char and pyrolytic lignin form gel-like phase and affect the liquid collection. Cause oil aging. Sedimentation. Filter blockage, catalyst blockage, and engine injector blockage.

$[8,12,15,51,95]$

$[12,51,89,92$,

$[12,51,92,99$,

$100,109]$.

\section{$[8,51,101]$}

Enrich in wood ash, 8 - 300 ppm. Form fly ash and aerosols and cause particulate emissions. Affect

$[8,51,101]$ char/ash utilization and disposal. Require gas cleaning devices. Affect oil clean up.

Enrich in wood ash, 80-1900 ppm, e.g., 260 -500 ppm in spruce chips, 300-940 ppm in spruce bark, 60-90

ppm in wheat straw, 120-200 wheat cereals. Form fly ash and aerosols and cause particulate emissions. 
Affect char/ash utilization and disposal. Require gas cleaning devices. Affect oil clean up.

In wood and herbaceous, $0.04-70 \mathrm{ppm}$. Least bound in pure lignin. Form fly ash and aerosols and cause

$[8,51,101]$ particulate emissions. Affect char/ash utilization and disposal. Require gas cleaning devices. Affect oil clean up.

High in wood ash, $0.2-26$ ppm. Most bound in demineralized wood, pure cellulose and lignin. Form fly ash and aerosols and cause particulate emissions. Affect char/ash utilization and disposal. Require gas cleaning devices. Affect oil clean up. disposal. Require gas cleaning devices. Affect oil clean up. Affect char/ash utilization and disposal. Require gas cleaning devices. Affect oil clean up. 
Table 5. Effect of compositional attributes on HTL conversion and upgrading

\begin{tabular}{|c|c|c|}
\hline $\begin{array}{l}\text { Compositional } \\
\text { properties }\end{array}$ & Impact on HTL bio-crude oil & Reference \\
\hline Ash & $\begin{array}{l}\text { Affect solid residue yield, bio-crude yield and product distribution. Covers the surface of organic matter, } \\
\text { hamper mass transfer and thermal chemical reaction. Require solid/liquid separation step following HTL } \\
\text { to have solids-free and mineral-free bio-crude. Higher ash content, lower lignin content lead to a higher } \\
\text { conversion rate and yield. Difficulties for upgrading process. Catalytic effect on vapor cracking. Cause } \\
\text { phase separation, poor mixing. Difficulty in handling, storage and processing. Traces quantities can } \\
\text { affect the product. }\end{array}$ & {$[18,113-116,133,134]$} \\
\hline $\begin{array}{l}\text { Alkaline and } \\
\text { alkaline earth } \\
\text { metals }\end{array}$ & $\begin{array}{l}\text { Natural catalyst. Catalytic effect: } \mathrm{K}_{2} \mathrm{CO}_{3}>\mathrm{KOH}>\mathrm{Na}_{2} \mathrm{CO}_{3}>\mathrm{NaOH} . \mathrm{K}_{2} \mathrm{CO} 3 \text { effect on heavy oil yield } \\
\text { depends on lignin content, the lower the lignin content, the weaker the catalytic effect. } \\
\mathrm{K}_{2} \mathrm{CO}_{3} \text { or } \mathrm{Ca}(\mathrm{OH})_{2} \text { increase the conversion yield. K-containing ash component has the highest catalytic } \\
\text { effects. Affect the molecular weights of the bio-crude oils. Affect the quality of oils, i.e., O/C ratio and } \\
\text { HHV. Calcium phosphate precipitates in the solids, requiring separation. }\end{array}$ & {$[18,114,116,118,135]$.} \\
\hline Chloride & Cause chloride stress corrosion on stainless steel reactor component. & {$[18,117]$} \\
\hline Nitrogen & $\begin{array}{l}\text { Interact with degradation products and form solid deposits. Require hydro-treatment to minimize catalyst } \\
\text { deactivation and improve oil stability. Produce NOx and cause air pollution. }\end{array}$ & {$[18,111,112]$} \\
\hline Sulfur & Produce SOx and cause air pollution. Cause increased equipment wear and deposit formation. & {$[111,117,118]$} \\
\hline
\end{tabular}

